\title{
Effect of Lactic Acid Bacteria Starter Cultures on Vitamin and Oligosaccharide Composition of Milk Extracted from Three Common Bean (Phaselous Vulgaris L) Varieties
}

\author{
Calvince Anino ${ }^{1,2}$, Arnold Onyango ${ }^{1}$, Samuel Imathiu ${ }^{1} \&$ Julius Maina $^{1}$ \\ ${ }^{1}$ Department of Food Science and Technology, Jomo Kenyatta University of Agriculture and Technology, Kenya \\ ${ }^{2}$ Department of Environmental Health, University of Kabianga, Kenya \\ Correspondence: Calvince Anino, Department of Food Science and Technology, Jomo Kenyatta University of \\ Agriculture and Technology, Kenya. E-mail: calvinceanino@yahoo.com
}

\author{
Received: March 22, 2019 Accepted: April 8, $2019 \quad$ Online Published: May 7, 2019 \\ doi:10.5539/jfr.v8n3p103 URL: https://doi.org/10.5539/jfr.v8n3p103
}

\begin{abstract}
Fermented foods have in recent times attracted consumer interest mainly due to perceived health benefits of probiotic microorganisms. This study characterized changes in the concentrations of selected B-complex vitamins and oligosaccharides of common bean milk during fermentation by a common dairy starter culture, YF L-903 (Streptococcus thermophilus + Lactobacillus Bulgaricus subs Debulgaricus), and three probiotic cultures namely ABT (Lactobacillus acidophilus La-5 + Bifidobacterium animalis Bb-12 + Streptococcus thermophilus), Yoba (Lactobacillus rhamnosus yoba + Streptococcus thermophilus), and Yoba Fiti (Lactobacillus rhamnosus GR1 + Streptococcus thermophilus). Bean milk was prepared from three common bean varieties. It was found that, apart from thiamine (vitamin B1) and riboflavin (vitamin B2), fermentation with each of the mixed cultures caused significant increase in the vitamin B complex. Significant reductions $(\mathrm{p}<0.05)$ in the oligosaccharides concentration of the bean milks were observed upon fermentation. Highest reduction in the oligosaccharide sugars of $77.8 \%$ was found in milk from pinto bean variety fermented with ABT culture. These findings suggest that $\mathrm{LAB}$ probiotic cultures have a potential for improving biosynthesis of vitamins and removal of the verbascose, stachyose and raffinose oligosaccharides, thus making the product more digestible and the nutrients more bioavailable.
\end{abstract}

Keywords: common bean, bean milk, fermentation, vitamin biosynthesis

\section{Introduction}

In developing nations dietary deficiencies, especially in vitamins is reported to cause various health disorders (UNICEF, 2011). However, in developed nations consumers are concerned with their recommended dietary intake and usually use vitamins as supplements to promote health and prevent chronic diseases (Burgess, Smid, \& Sinderen, 2009; Fortmann et al., 2013). Although the major role of food in the body is to provide adequate nutrients to meet daily metabolic requirements, recent findings suggest that food may regulate several functions beyond the predictable nutritional benefit (Stanton et al., 2001). Therefore, fermented foods, particularly those fermented with probiotic cultures have in recent times attracted the interest of the consumers, due to their perceived health benefits including bioavailability of nutrients such as vitamins (LeBlanc et al., 2010) and reduction or improved oligosaccharides digestion (Difo et al., 2015).

Vitamins are generally classified into two groups, the fat soluble vitamins (A, D, E and K) and the water soluble vitamins which include a series of B-vitamins, vitamin C and biotin (Burgess et al., 2009). The B-complex or B group vitamins is comprised of thiamine (B1), riboflavin (B2), niacin (B3), pantothenic acid (B5), biotin (H or B7), folate (M, B9 or B11) and cobalamin (B12) (Capozzi et al., 2012). Owing to their water solubility the B group vitamins play an important role in cellular metabolism of fats and protein (pyridoxine and riboflavin) and carbohydrates (thiamine), where they act as coenzymes, principally as carriers of a specific chemical group (Baku \& Dickerson, 1996). These molecules are normally present in a number of foods, but can easily be destroyed or removed during food processing which potentially explains why their deficiency is rather common in a large population (Capozzi et al., 2012). Thus, food industries have been subjected by laws in the country of their operations to fortify certain foods with specific B-complex vitamins (LeBlanc et al., 2010). 
Prokaryotes, including some lactic acid bacteria (LAB) utilize B-vitamins to meet their nutritional requirements (Snell, 1993). However, production of these vitamins by LAB has also been established (LeBlanc et al., 2011). This natural ability for vitamin B-complex biosynthesis by LAB has the potential to be utilized, either to harness the natural biosynthetic pathway of these microorganisms in fortification of fermented foods or to replace costly chemical synthesis of such foods (Burgess et al., 2009).

Oligosaccharides in common beans are about 31 to $76 \%$ of the total sugars and are known to cause flatulence and discomfort in the stomach (Campos et al., 2009; Campos et al., 2013). Traditional processing methods such as soaking and de-hulling followed with thermal treatment can eliminate most of these oligosaccharides in common bean but require a lot of energy, which is costly, particularly in developing countries (Nakitto, Muyonga, \& Nakimbugwe, 2015). Little research has been done on the role of combined processing methods such as soaking, de-hulling, fermentation and steaming on nutritional quality and production of nutritious fast cooking common bean product (Nakitto et al., 2015), yet fermentation could sequestrate oligosaccharides (Kort et al., 2015). Therefore, this study was carried out to develop a milk product from beans and to characterize changes in the concentrations of the B-complex molecules and oligosaccharides sugars of common bean milk.

\section{Materials and Methods}

\subsection{Bean Collection and Storage}

Local varieties of dry pinto beans, red haricot beans and yellow kidney beans were procured from a trader in Nairobi County, Kenya. One packet containing $2 \mathrm{Kg}$ of each of the bean variety was bought, wrapped in a kraft paper and transported to the food technology workshop in the School of Food and Nutritional Sciences of the Jomo Kenyatta University of Agriculture and Technology (JKUAT). The dry beans were stored in sealed plastic containers at room temperature $\left(20\right.$ to $\left.25^{\circ} \mathrm{C}\right)$ until use.

\subsection{Bean Milk Preparation and Fermentation}

Bean milk was prepared using methods of Anino et al. (2019). Briefly, $100 \mathrm{~g}$ of common beans was rinsed and soaked in a $1 \mathrm{~L}$ of deionized water for $16 \mathrm{~h}$ at room temperature $\left(23^{\circ} \mathrm{C}\right)$. Water was drained off and the seeds dehulled by hand and ground in a blender (MBLR4314/WH, Mika, Dubai, UAE) for 3 min at 550W with 1L boiling water. The resulting slurry was filtered through 2 layers of muslin cloth to allow only water soluble common bean milk to pass through. The strained milk was heated in a heavy bottom pan to $100^{\circ} \mathrm{C}$ for 20 min, stirring frequently to prevent sticking. The heat treated bean milk was placed at room temperature $\left(20\right.$ to $\left.25^{\circ} \mathrm{C}\right)$ and left to cool for 2 hours and thereafter stored at $4^{\circ} \mathrm{C}$.

With regards to fermentation method used by Mani, Palou, \& López (2014) was adopted with slight modifications. Briefly, LAB strains contained in a common dairy starter culture, YF L-903 (Streptococcus thermophilus + Lactobacillus Bulgaricus subs Debulgaricus), and three probiotic cultures namely ABT (Lactobacillus acidophilus La-5 + Bifidobacterium animalis Bb-12 + Streptococcus thermophilus), Yoba (Lactobacillus rhamnosus yoba + Streptococcus thermophilus), and Yoba Fiti (Lactobacillus rhamnosus GR1 + Streptococcus thermophilus) were used to ferment the bean milks. Each of the four starter cultures was prepared to yield equal amount of fermented milk for the three different bean milk varieties as follows. A $0.5 \mathrm{~g}$ of each of the starter culture was inoculated in $500 \mathrm{ml}$ of raw milk. The inoculated bean milk was incubated at $45^{\circ} \mathrm{C}$ in a Heratherm microbilogical incubator until a $\mathrm{pH} \leq 4.3$ was attained. The fermented bean milk was placed at room temperature $\left(20\right.$ to $\left.25^{\circ} \mathrm{C}\right)$ and left to cool for 2 hours and thereafter stored at $4^{\circ} \mathrm{C}$. Eppendorf tubes of $5 \mathrm{ml}$ fermented milk were taken in triplicates to determine the concentration of B-vitamins (thiamine, riboflavin, niacin, pyridoxine and folic acid) and eppendorf tubes of $10 \mathrm{ml}$ oligosaccharides (raffinose, stachyose and verbascose).

\subsection{Determination of Thiamine, Riboflavin, Pyridoxine and Folic Acid}

Extraction of thiamine, riboflavin, pyridoxine, niacin and folic acid was based on the modified methods of Chase et al. (1993); Ekinci \& Kadakal (2005) and Kamman, Labuza, \& Warthesen (1980). The extractions were carried out in triplicates by adding $20 \mathrm{ml}$ of deionized water to $5 \mathrm{ml}$ of bean milk (dilution factor, $F,=5 \mathrm{ml}$ ). The mixture was homogenized using a homogenizer at medium speed for $1 \mathrm{~min}$. The homogenized mixture was centrifuged for $15 \mathrm{~min}$ at $1500 \mathrm{rpm}$ and Sep-Pak C18 $(500 \mathrm{mg}$ ) cartridges method of Cho et al. (Cho, Ko, \& Cheong, 2000) was used to extract the water-soluble vitamins. The extracts were filtered through a $0.45 \mu \mathrm{m}$ micropore membrane FP 30/45 CA-S filters (Schleicher and Schuell, Darmstadt, Germany). A $0.45 \mu \mathrm{m}$ of the filtrate was injected with a syringe into HPLC column (20A Series, Shimadzu Co-operation, Kyoto, Japan) C18 $150 \mathrm{~mm} \times 4.6 \mathrm{~mm}$ with a flow rate of $0.1 \mathrm{~mol} \mathrm{~L}^{-1}$ and $\mathrm{KH}_{2} \mathrm{PO}_{4}$ (PH 7.0)-methanol, 90:10, as mobile phase (0.7 $\mathrm{mL} \mathrm{min}^{-1}$ ) in isocratic mode. The vitamins were identified by comparing their retention times and UV-visible 
spectra with those of standards stored in a data bank at $266 \mathrm{~nm}$ for riboflavin, $282 \mathrm{~nm}$ for folic acid, $234 \mathrm{~nm}$ for thiamine, $324 \mathrm{~nm}$ for pyridoxine and $261 \mathrm{~nm}$ for niacin.

\subsection{Determination of Oligosaccharides}

The methods of Brenes et al. (2003) and Campos et al. (2009) were modified to determine three forms of oligosaccharides; raffinose, stachyose and verbascose in triplicates. A10 ml sample of common bean milk was homogenized in aqueous ethanol $(100 \mathrm{ml}, 80 \%, \mathrm{v} / \mathrm{v})$ and placed in a Soxhlet at $80^{\circ} \mathrm{C}$ for $60 \mathrm{~min}$. The ethanol extracts was recovered, concentrated under vacuum, and the water phase frozen and lyophilized. A $7 \mathrm{mg}$ sample of the extracted oligosaccharides was re-dissolved in $1 \mathrm{ml}$ of deionized water, filtered and subjected to HPLC analysis. Standard curves were determined by injecting $20 \mu \mathrm{l}$ of raffinose, stachyose and verbascose standards into HPLC column (20A Series, Shimadzu Cooperation, Kyoto, Japan) connected to a refractive index detector fitted with a Zorbax $\mathrm{NH}_{2}$ pre-column $(4.6 \times 12.6 \mathrm{~mm}, 5 \mu \mathrm{m})$ and Zorbax column $(250 \times 4.6 \mathrm{~mm})$. A $20 \mu \mathrm{l}$ of the extracted oligosaccharides was also injected into HPLC column to obtain peak areas. Water/acetonitrile (65:35) was used as mobile phase at $1 \mathrm{ml} / \mathrm{min}$. Column and detector temperatures were maintained at $25^{\circ} \mathrm{C}$.

\subsection{Statistical Analysis}

All data were subjected to two way full factorial ANOVA using STATA/SE 12.0 software for windows to identify significant treatment effects. Comparison among means for different groups was made using Bonferroni least significant difference (LSD) test at $\mathrm{p} \leq 0.05$.

\section{Results and Discussion}

\subsection{Vitamin Concentration of Fermented Bean Milk}

Table 1. Vitamin concentration in milk extracted from red haricot $(\mathrm{RH})$, yellow kidney $(\mathrm{YK})$ and pinto $(\mathrm{P})$ common bean varieties fermented with LAB probiotic starter cultures; ABT (Lactobacillus acidophilus La-5 + Bifidobacterium animalis Bb-12 + Streptococcus thermophilus), YF L-903 (Streptococcus thermophilus + Lactobacillus Bulgaricus subs Debulgaricus), Yoba (Lactobacillus rhamnosus yoba + Streptococcus thermophilus) and Yoba Fiti (Lactobacillus rhamnosus GR1 + Streptococcus thermophilus)

\begin{tabular}{|c|c|c|c|c|c|c|c|c|c|c|c|c|c|c|c|}
\hline & \multicolumn{3}{|c|}{ Thiamine (mg/100g) } & \multicolumn{3}{|c|}{ Riboflavin $(\mu \mathrm{g} / 100 \mathrm{~g})$} & \multicolumn{3}{|c|}{ Niacin (mg/100g) } & \multicolumn{3}{|c|}{ Pyridoxine (mg/100g) } & \multicolumn{3}{|c|}{ Folic acid (mg/100g) } \\
\hline & RH & YK & $\mathrm{P}$ & RH & YK & $\mathrm{P}$ & RH & $\mathrm{YK}$ & $\mathrm{P}$ & RH & $\mathrm{YK}$ & $\mathrm{P}$ & RH & YK & $\mathrm{P}$ \\
\hline NF & $0.2 \pm 0.0^{\mathrm{a}}$ & $0.2 \pm 0.0^{\mathrm{a}}$ & $0.2 \pm 0.0^{\mathrm{a}}$ & $88.1 \pm 1.6^{\mathrm{c}}$ & $52.2 \pm 3.4^{\mathrm{b}}$ & $40.0 \pm 4.7^{\mathrm{ab}}$ & $0.5 \pm 0.0^{\mathrm{a}}$ & $0.4 \pm 0.0^{\mathrm{a}}$ & $0.5 \pm 0.1^{\mathrm{a}}$ & $0.1 \pm 0.0^{\mathrm{a}}$ & $0.1 \pm 0.0^{\mathrm{a}}$ & $0.1 \pm 0.0^{\mathrm{a}}$ & $0.3 \pm 0.0^{\mathrm{a}}$ & $0.4 \pm 0.0^{\mathrm{b}}$ & $0.4 \pm 0.0^{\mathrm{bc}}$ \\
\hline Yoba & ND & $\mathrm{ND}$ & ND & $27.8 \pm 0.5^{\mathrm{a}}$ & $57.7 \pm 3.0^{\mathrm{b}}$ & $49.9 \pm 9.1^{\mathrm{b}}$ & $1.2 \pm 0.1^{\mathrm{b}}$ & $2.3 \pm 0.0^{\mathrm{c}}$ & $1.3 \pm 0.0^{\mathrm{b}}$ & $0.3 \pm 0.0^{\mathrm{c}}$ & $0.2 \pm 0.0^{\mathrm{b}}$ & $0.5 \pm 0.0^{\mathrm{e}}$ & $0.4 \pm 0.0^{\mathrm{b}}$ & $0.6 \pm 0.1^{\mathrm{cd}}$ & $0.6 \pm 0.1^{\mathrm{cd}}$ \\
\hline YF & ND & ND & ND & $50.1 \pm 0.2^{\mathrm{b}}$ & $60.1 \pm 10.6^{\mathrm{b}}$ & $33.9 \pm 4.7^{\mathrm{ab}}$ & $3.7 \pm 0.4^{\mathrm{d}}$ & $2.8 \pm 0.2^{\mathrm{cd}}$ & $3.0 \pm 0.4^{\mathrm{cd}}$ & $0.2 \pm 0.0^{\mathrm{b}}$ & $0.2 \pm 0.0^{\mathrm{b}}$ & $0.2 \pm 0.0^{\mathrm{b}}$ & $0.5 \pm 0.0^{\mathrm{c}}$ & $0.9 \pm 0.1^{\mathrm{e}}$ & $0.6 \pm 0.1^{\mathrm{cd}}$ \\
\hline L-903 & & & & & & & & & & & & & & & \\
\hline ABT & ND & ND & ND & $433.0 \pm 63.7^{\mathrm{d}}$ & $1121.9 \pm 15.9^{f}$ & $670.9 \pm 26.1^{\mathrm{e}}$ & $2.8 \pm 0.2^{\mathrm{cd}}$ & $2.2 \pm 0.1^{\mathrm{c}}$ & $2.8 \pm 0.1^{\mathrm{cd}}$ & $1.0 \pm 0.1^{\mathrm{f}}$ & $0.5 \pm 0.1^{\mathrm{de}}$ & $1.0 \pm 0.0^{\mathrm{f}}$ & $0.6 \pm 0.0^{\mathrm{d}}$ & $0.9 \pm 0.1^{\mathrm{e}}$ & $0.7 \pm 0.1^{\mathrm{de}}$ \\
\hline Yoba & ND & ND & ND & $23.8 \pm 0.6^{\mathrm{a}}$ & $27.8 \pm 1.1^{\mathrm{a}}$ & $21.2 \pm 0.1^{\mathrm{a}}$ & $3.6 \pm 0.3^{\mathrm{d}}$ & $2.4 \pm 0.4^{\mathrm{c}}$ & $3.0 \pm 0.8^{\mathrm{cd}}$ & $0.4 \pm 0.0^{\mathrm{d}}$ & $0.3 \pm 0.0^{\mathrm{c}}$ & $0.4 \pm 0.1^{\mathrm{cd}}$ & $0.5 \pm 0.0^{\mathrm{c}}$ & $0.8 \pm 0.0^{\mathrm{e}}$ & $0.5 \pm 0.0^{\mathrm{c}}$ \\
\hline Fiti & & & & & & & & & & & & & & & \\
\hline SE & 0.01 & & & 8.8 & & & 0.26 & & & 0.01 & & & 0.01 & & \\
\hline P & $<0.01$ & & & $<0.01$ & & & $<0.01$ & & & $<0.01$ & & & $<0.01$ & & \\
\hline
\end{tabular}

NB: Results are means \pm standard deviation (SD). Different superscript letters within the same column and row indicate statistical significance (Bonferroni, $\mathrm{p}<0.05$ ); NF, non-fermented; ND, not detectable.

The effects of fermentation on vitamin concentration of common bean milk extracted from the three bean varieties are shown in Table 1. There were no significant inter-varietal differences in the contents of thiamine, niacin and pyridoxine in raw bean milk, while the differences in riboflavin and folic acid were significant $(\mathrm{p}<0.05)$. Thiamine was not quantifiable in bean milk fermented with any of the cultures. This is consistent with the results of (Granito et al., 2002) who observed notable losses in thiamine after natural fermentation of lentils and red beans.

The starter cultures had different effects on the riboflavin content of beans (Table 1) which is consistent with previous reports that $\mathrm{LAB}$ strains can produce or utilize individual vitamin B molecules, depending with the genome of the fermenting microorganism (Burgess et al., 2009). Fermentation with Yoba Fiti culture significantly reduced $(\mathrm{p}<0.05)$ riboflavin in milk extracted from the three bean varieties by $46.7 \%$ to $73 \%$. An earlier study by Elmadfa et al. (2001) showed that most probiotic strains of lactobacilli consume riboflavin thereby decreasing its bioavailability. Additionally, riboflavin biosynthesis has been shown to occur when the four genes; ribG, ribB, ribA and ribH are present in the microbes genome (Bacher et al., 2015). However, absence of the ribG is previously reported for L. rhamnosus GR1, L. rhamnosus yoba, L. bulgaricus and $S$. thermophilus (Thakur et al., 2015; Valle et al., 2014). On the hand, the bean variety from which milk was extracted had great influence on the riboflavin concentration of the fermented milk. For example, fermentation 
with Yoba significantly reduced riboflavin content in milk extracted from red haricot but not in milk extracted from the other two varieties, while fermentation with ABT caused great increases of this vitamin in milk extracted from all the varieties, especially in milk extracted from yellow kidney beans (>2000\% increase). Bifidobacterium animalis Bb-12 and L. acidophilus La-5 which are the fermenting bacteria in the mixed probiotic ABT culture contain the four gene operons needed to catalyze biosynthesis of riboflavin (Thakur et al., 2015). Thus, appropriate selection of species and/or strains is essential in increasing riboflavin of fermented bean milk.

Fermentation caused significant increase $(\mathrm{p}<0.01)$ in niacin concentration of the milk extracted from the three bean varieties. The niacin values in milk extracted from red haricot beans fermented with Yoba and L-903 cultures increased from $0.5 \pm 0.0 \mathrm{mg} / 100 \mathrm{~g}$ to $1.2 \pm 0.1 \mathrm{mg} / 100 \mathrm{~g}$ and $3.7 \pm 0.4 \mathrm{mg} / 100 \mathrm{~g}$ respectively (Table 1 ). The highest increase in niacin concentration in milk extracted from the three bean varieties, an increase of $640 \%$ was found in milk extracted from red haricot beans fermented with YF-L903 culture. Increase in niacin values of cheese and yoghurt fermented with lactic acid producing bacteria was earlier reported $(\mathrm{Gu} \& \mathrm{Li}, 2016)$. These strains may be useful in enriching niacin composition of bean milk and could be exploited for other legumes.

With regards to pyridoxine the highest concentration was quantified in milk fermented with ABT culture (Table 1). Similarly, the highest increase of $900 \%$ was found in milk extracted from red haricot and pinto beans fermented with ABT cultures. A previous study by Vajaranant \& Fields (1989) reported increase $(\mathrm{p}<0.05)$ in pyridoxine values of corn meal $(0.52 \pm 0.0$ to $0.72 \pm 0.1 \mathrm{mg} / 100 \mathrm{~g})$ fermented with different strains of Bacilus licheniformis. Similarly, fermentation of soy with different species and strains of Streptococcus thermophilus, Lactobacilluis helveticus and Bifidobacterium longum was previously reported to cause significant increases in pyridoxine concentration (Champagne et al., 2010). The biosynthesis of pyridoxine was previously reported to depend on the microbial ecological niche (Qaidi et al., 2013). This could imply that L. acidophilus and B. animals have got specific metabolic properties that make them more efficient in the biosynthesis of folic acid than other LAB (Table 1).

Milk extracted from yellow kidney beans and pinto beans had statistically higher $(\mathrm{p}<0.05)$ folic acid of $0.4 \pm 0.0$ $\mathrm{mg} / 100 \mathrm{~g}$ than those extracted from red haricot beans which contained $0.3 \pm 0.0 \mathrm{mg} / 100 \mathrm{~g}$. Folic acid was significantly higher $(\mathrm{p}<0.05)$ in corresponding fermented bean milk than the non-fermented milk (Table 1$)$. This agrees with earlier studies which reported increase in folic acid in milk fermented with L. rhamnosus (Hugenschmidt et al., 2010), S. thermophilus (Lai no, LeBlanc, \& Savoy, 2012), L. acidophilus (Lai no et al., 2014), and B. animalis (Pompei et al., 2007). Milk extracted from yellow kidney beans exhibited relatively higher increase in folate than the other two bean varieties. Additionally, the highest increase in folic acid in each milk category was found in those fermented with ABT culture, an increase of (75 to 125\%). L. acidophilus strains is reported to contain folate biosynthesis cluster which converts 6-hydroxymetheyl-7,8-dihydropterin (DHPP) to folic acid biosynthesis precursor parabenzoic amino acid (pABA) (Gu \& $\mathrm{Li}, 2016)$. However, $L$. rhamnosus and S. thermophilus use an alternative biosynthesis pathway (KEGG, 2014) which could be less efficient in the biosynthesis of folic acid (Table 1).

\subsection{Oligosaccharides Concentration of Fermented Bean Milk}

Table 2. Oligosaccharides concentration $(\mathrm{mg} / 100 \mathrm{~g})$ in milk extracted from red haricot $(\mathrm{RH})$, yellow kidney (YK) and pinto $(\mathrm{P})$ common bean varieties fermented with LAB probiotic starter cultures; ABT (Lactobacillus acidophilus La-5 + Bifidobacterium animalis Bb-12 + Streptococcus thermophilus), YF L-903 (Streptococcus thermophilus + Lactobacillus Bulgaricus subs Debulgaricus), Yoba (Lactobacillus rhamnosus yoba + Streptococcus thermophilus) and Yoba Fiti (Lactobacillus rhamnosus GR1 + Streptococcus thermophilus)

\begin{tabular}{|c|c|c|c|c|c|c|c|c|c|}
\hline & \multicolumn{3}{|c|}{ Raffinose (mg/100g) } & \multicolumn{3}{|c|}{ Verbascose $(\mathbf{m g} / \mathbf{1 0 0 g})$} & \multicolumn{3}{|c|}{ Stachyose $(\mathrm{mg} / \mathbf{1 0 0 g})$} \\
\hline & RH & YK & $\mathrm{P}$ & $\mathrm{RH}$ & YK & $\mathrm{P}$ & RH & YK & $\mathrm{P}$ \\
\hline $\mathrm{NF}$ & $0.4 \pm 0.0^{\mathrm{d}}$ & $0.4 \pm 0.0^{\mathrm{d}}$ & $0.4 \pm 0.0^{\mathrm{d}}$ & $0.2 \pm 0.0^{\mathrm{b}}$ & $0.4 \pm 0.0^{\mathrm{d}}$ & $0.3 \pm 0.0^{\mathrm{c}}$ & $3.4 \pm 0.1^{\mathrm{g}}$ & $4.2 \pm 0.2^{\mathrm{h}}$ & $3.6 \pm 0.4^{\text {gh }}$ \\
\hline Yoba & $0.2 \pm 0.1^{\mathrm{abc}}$ & $0.2 \pm 0.0^{\mathrm{b}}$ & $0.3 \pm 0.0^{\mathrm{c}}$ & $0.1 \pm 0.0^{\mathrm{a}}$ & $0.1 \pm 0.0^{\mathrm{a}}$ & $0.1 \pm 0.0^{\mathrm{a}}$ & $1.0 \pm 0.0^{\mathrm{b}}$ & $1.3 \pm 0.1^{\mathrm{bcd}}$ & $2.3 \pm 0.4^{\mathrm{ef}}$ \\
\hline YF L-903 & $0.2 \pm 0.0^{\mathrm{ab}}$ & $0.2 \pm 0.1^{\mathrm{abc}}$ & $0.2 \pm 0.0^{\mathrm{b}}$ & $0.2 \pm 0.1^{\mathrm{abc}}$ & $0.1 \pm 0.1^{\mathrm{ab}}$ & $0.1 \pm 0.0^{\mathrm{a}}$ & $2.6 \pm 0.4^{\mathrm{f}}$ & $1.6 \pm 0.1^{\text {de }}$ & $1.1 \pm 0.2^{\mathrm{acd}}$ \\
\hline $\mathrm{ABT}$ & $0.1 \pm 0.1^{\mathrm{ab}}$ & $0.2 \pm 0.0^{\mathrm{b}}$ & $0.1 \pm 0.0^{\mathrm{a}}$ & $0.1 \pm 0.0^{\mathrm{a}}$ & $0.1 \pm 0.0^{\mathrm{a}}$ & $0.1 \pm 0.0^{\mathrm{a}}$ & $0.9 \pm 0.2^{\mathrm{ab}}$ & $1.0 \pm 0.1^{\mathrm{ab}}$ & $0.8 \pm 0.0^{\mathrm{a}}$ \\
\hline Yoba Fiti & $0.2 \pm 0.0^{\mathrm{ab}}$ & $0.2 \pm 0.1^{\mathrm{abc}}$ & $0.2 \pm 0.0^{\mathrm{b}}$ & $0.1 \pm 0.0^{\mathrm{a}}$ & $0.1 \pm 0.1^{\mathrm{a}}$ & $0.1 \pm 0.0^{\mathrm{a}}$ & $1.6 \pm 0.2^{\text {bcde }}$ & $1.1 \pm 0.1^{\mathrm{abc}}$ & $1.0 \pm 0.1^{\mathrm{ab}}$ \\
\hline SE & & 0.02 & & & 0.02 & & & 0.12 & \\
\hline $\mathrm{P}$ & & $<0.01$ & & & $<0.01$ & & & $<0.01$ & \\
\hline
\end{tabular}

NB: Results are means \pm SD. Different superscript letters within the same column and row indicate statistical significance (Bonferroni, $\mathrm{p}<0.05$ ); NF, non-fermented.

There are various types of oligosaccharide sugars, including raffinose, verbascose and stachyose. These sugars 
are known to cause flatulence and are partly the reason for low consumption of common beans and its associated products (Paredes \& Harry, 1989). Table 2 shows the effects of fermentation on oligosaccharides concentration of common bean milk extracted from three bean varieties. A narrow range of values have been reported for raffinose in legumes. For instance, Difo et al. (2015) found that racemosa seeds contained $1.9 \pm 0.0 \mathrm{mg} / 100 \mathrm{~g}$ of raffinose sugars while Akinyele \& Akinlosotu (1991) reported concentration of $2.0 \pm 0.0 \mathrm{mg} / 100 \mathrm{~g}$ in cowpeas (Vigna unguiculata). Thus, the concentration of $0.4 \pm 0.0 \mathrm{mg} / 100 \mathrm{~g}$ contained in non-fermented bean milk was far much lower than the previously reported values for most legumes. Similar to the results of Da et al., (2006) stachyose $(3.4 \pm 0.1$ to $4.2 \pm 0.2 \mathrm{mg} / 100 \mathrm{~g}$ ) was the most abundant oligosaccharide sugar in non-fermented bean milk (Table 2). The highest reduction in raffinose concentration (75\%) was recorded in pinto bean milk fermented with ABT culture. A previous study by Granito \& Alvarez (2006) reported similar results when black beans varieties were fermented with lactic acid bacteria. The reduction in raffinose could be attributed to the utilization of the oligosaccharides for energy by the microorganisms. The current finding is of great interest as it suggests that fermentation could be used to reduce flatulence causing raffinose.

Fermentation with Yoba, ABT and Yoba Fiti cultures caused significant decreases $(p<0.05)$ in verbascose concentration of the milk extracted from red haricot beans ( $p>0.05$ ) (Table 2). Fermented milk extracted from yellow kidney and pinto beans were also found to contain statistically lower $(\mathrm{p}<0.05)$ verbascose values on average $(0.1 \pm 0.0 \mathrm{mg} / 100 \mathrm{~g})$ than non-fermented milk $(0.4 \pm 0.0 \mathrm{mg} / 100 \mathrm{~g})$ and $(0.3 \pm 0.0 \mathrm{mg} / 100 \mathrm{~g})$ respectively, a $75 \%$ reduction in verbascose concentration in milk extracted from yellow kidney beans. This agrees with earlier reports which had shown reduction in verbascose values of common beans upon fermentation (Starzynska, Bozena, \& Mickowska, 2014). LAB contains $\alpha$ galactosidase enzyme which potentially enables them to utilize verbascose sugars. However, there was variation in the utilization rate of verbascose (Table 2) among the fermenting $\mathrm{LAB}$ which could be due to differences in the expression of the $\alpha$-galactosidase enzyme.

Fermentation triggered significant reduction $(p<0.05)$ in stachyose values for the three bean milk, with the highest reduction of $77.8 \%$ observed in milk extracted from pinto bean variety fermented with ABT culture. Stachyose could have been hydrolyzed by $\alpha$-galactosidase into sucrose and galactose, and the latter metabolized through the galactose-utilization system (Da et al., 2006). Additionally, significantly higher $(\mathrm{p}<0.05)$ stachyose value was found in milk extracted from red haricot beans fermented with YF L903. This could be an indication that the ability of fermenting microorganisms to hydrolyze bonds in oligosaccharide moieties is dependent on enzymatic properties of the bacterial strain and the efficiencies of the $\alpha$-galactosidase activity of that particular strain. Thus, appropriate selection of the fermenting culture is a necessity in reducing stachyose in fermented bean milk.

\section{Conclusion}

Fermentation with each of the four cultures increased pyridoxine, niacin and folic acid concentrations of the three bean milks. However, thiamine was non-quantifiable in fermented milks while riboflavin values were lowered for all the fermenting cultures, except ABT culture. This implies that combination of probiotic strains of Lactobacillus acidophilus La-5 + Bifidobacterium animalis Bb-12 + Streptococcus thermophilus could be exploited for natural fortification of riboflavin in bean milk. It was also observed that fermentation significantly lowered the oligosaccharide compositions of stachyose, raffinose and verbascose. Thus, fermentation of bean milk with any of the four cultures could be utilized for removal of the flatulence causing oligosaccharides.

\section{Authors' contribution}

CA and AO participated in bean milk development and experimentations. SI and JM participated in conceptualization of the research design and performing the experiments. All authors read and approved the final manuscript.

\section{Acknowledgement}

The authors are thankful to the University of Kabianga for financing the study and Jomo Kenyatta University of Agriculture and Technology for the good will to use laboratory facilities. We are very grateful for the technical assistance granted to us by the technicians in the Biochemistry laboratory during the study.

\section{Conflict of interest}

The authors declare that there are no conflicts of interest.

\section{Availability of data and materials}

All the data and material supporting the conclusion of this work are included within the manuscript. Additional information may be provided on request by the corresponding author. 


\section{Consent for publication}

All authors have agreed to submit the manuscript in its current form for publication in the Journal of Food Research.

\section{Ethical approval and consent to participate}

Not applicable. No tests, measurements or experiments were performed on humans as part of this work.

\section{References}

Akinyele, I. O., \& Akinlosotu, A. (1991). Effect of Soaking, Dehulling and Fermentation on the Oligosaccharides and Nutrient Content of Cowpeas (Vigna Unguiculata). Food Chemistry, 41, 43-53.

Anino, C., Onyango, A. N., Imathiu, S., Maina, J., \& Onyangore, F. (2019). Chemical composition of the seed and ' milk' of three common bean (Phaseolus vulgaris L) varieties. Journal of Food Measurement and Characterization, 7(3), 1-10. https://doi.org/10.1007/s11694-019-00039-1

Bacher, A., Eberhardt, S., Fischer, M., Kis, K., \& Richter, G. (2000). Biosynthesi of Vitamin B2 (Riboflavin). Annu. Rev. Nutr., 20, 153-67.

Baku, T. K., \& Dickerson, J. W. T. (1996). Vitamins in HumanHealth and Disease. CAB International, Wallinford.

Brenes, A., Slominski, B. A., Marquardt, R. R., Guenter, W., \& Viveros, A. (2003). Effect of Enzyme Addition on the Digestibilities of Cell Wall Polysaccharides and Oligosaccharides from Whole, Dehulled, and Ethanol-Extracted White Lupins in Chickens. Poultry Science, 82, 1716-1725.

Burgess, C. M., Smid, E. J., \& Sinderen, D. Van. (2009). International Journal of Food Microbiology Bacterial vitamin B2 , B11 and B12 overproduction: An overview. International Journal of Food Microbiology, 133(1-2), 1-7. https://doi.org/10.1016/j.ijfoodmicro.2009.04.012

Campos, V. R., Oomah, D. L.-P., \& Guadalupe Vergara-Castaneda, A. (2013). Common Beans and Their Non-Digestible Fraction: Cancer Inhibitory Activity - An Overview. Journal of Food Science, 2, 374-392. https://doi.org/10.3390/foods2030374

Campos, V. R., Reynoso-Camacho, R., Pedraza-Aboytes, G., Acosta-Gallegos, J. A., Guzman-Maldonado, S. H., Paredes-Lopez, O., ... Loarca-Piña, G. (2009). Chemical composition and in vitro polysaccharide fermentation of different beans (Phaseolus Vulgaris L.). Journal of Food Science, 74(7), T59-T65. https://doi.org/10.1111/j.1750-3841.2009.01292.x

Capozzi, V., Russo, P., Dueñas, M. T., López, P., \& Spano, G. (2012). Lactic acid bacteria producing B-group vitamins: a great potential for functional cereals products. Applied Microbiol Biotechnol, 96, 1383-1394. https://doi.org/10.1007/s00253-012-4440-2

Champagne, C. P., Tompkins, T. A., Buckley, N. D., \& Greenjohnson, J. M. (2010). Effect of fermentation by pure and mixed cultures of Streptococcus thermophilus and Lactobacillus helveticus on isoflavone and B-vitamin content of a fermented soy beverage. Food Microbiol., 27, 968-972.

https://doi.org/10.1016/j.fm.2010.06.003

Chase, G. W., Landen, W. O., Soliman, A. G., \& Eitenmiller, R. R. (1993). Method modification for liquid chromatographic determination of thiamine, riboflavin, and pyridoxine in medical foods. J AOAC Int., 76(6), 1276-80.

Cho, C., Ko, J., \& Cheong, W. (2000). Simultaneous determination of water-soluble vitamins excreted in human urine after eating an overdose of vitamin pills by a HPLC method coupled with a solid phase extraction. Talanta, 51, 799-806.

Da, I., Fialho, S., Eria, V. A. L., \& Vic, U. F. De. (2006). Biochemical Composition and Indigestible Oligosaccharides in Phaseolus vulgaris L. Seeds. Plant Foods for Human Nutrition, 61, 87-89. https://doi.org/10.1007/s11130-006-0019-3

Difo, V. H., Onyike, E., Ameh, D. A., Njoku, G. C., \& Ndidi, U. S. (2015). Changes in nutrient and antinutrient composition of Vigna racemosa flour in open and controlled fermentation. J Food Sci Technol, 52(September), 6043-6048. https://doi.org/10.1007/s13197-014-1637-7

Ekinci, R., \& Kadakal, C. (2005). Determination of seven water soluble vitamins in tarhana, a traditional Turkish cereal food, by high-performance liquid chromatography. ACTA CHROMATOGRAPHICA, 15, 289-297.

Elmadfa, I., Heinzlle, C., Majchrzak, D., \& Foissy, H. (2001). Influence of a Probiotic Yoghurt on the Status of 
Vitamins B1, B2 and B6 in the Healthy Adult Human. Ann Nutr Metab, 45, 13-18.

Fortmann, S. P., Burda, B. U., Senger, C. A., Lin, J. S., \& Whitlock, P. E. (2013). Review Annals of Internal Medicine Vitamin and Mineral Supplements in the Primary Prevention of Cardiovascular Disease and Cancer : An Updated Systematic Evidence. Annals of Internal Medicine, 159(7), 824-834.

Granito, M., \& Alvarez, G. (2006). Lactic acid fermentation of black beans (Phaseolus vulgaris): microbiological and chemical characterization. Journal of the Science of Food and Agriculture, 86, 1164-1171. https://doi.org/10.1002/jsfa

Granito, M., Frias, J., Doblado, R., Guerra, M., \& Concepci, M. C. (2002). Nutritional improvement of beans (Phaseolus vulgaris) by natural fermentation. Eur Food Res Technol, 214, 226-231. https://doi.org/10.1007/s00217-001-0450-5

Gu, Q., \& Li, P. (2016). Biosynthesis of Vitamins by Probiotic Bacteria. In Probiotics and Prebiotics in Human and Health (pp. 136-48). China: INTECH: Open Science Open Mind.

Hugenschmidt, S., Schwenninger, S. M., Gnehm, N., \& Lacroix, C. (2010). Screening of a natural biodiversity of lactic and propionic acid bacteria for folate and vitamin B12 production in supplemented whey permeate. Int. Dairy J., 20, 852-857.

Kamman, J. F., Labuza, T. P., \& Warthesen, J. J. (1980). Thiamin and Riboflavin Analysis By High Performance Liquid Chromatography. Journal of Food Science, 45(6), 1497-1499.

https://doi.org/10.1111/j.1365-2621.1980.tb07548.x

KEGG. (2014). Genes and Genomes. In Kyoto Encyclopedia.

Kort, R., Westerik, N., Mariela Serrano, L., Douillard, F. P., Gottstein, W., Mukisa, I. M., ... Sybesma, W. (2015). A novel consortium of Lactobacillus rhamnosus and Streptococcus thermophilus for increased access to functional fermented foods. Microbial Cell Factories, 14(1), 195. https://doi.org/10.1186/s12934-015-0370-x

Lai no, J. E., Juarez, M., Savoyi, G., \& LeBlanc, J. G. J. (2014). Applicability of a Lactobacillus amylovorus strain as co-culture for natural folate bio-enrichment of fermented milk. Int. J. Food Microbiol., 191, 10-16.

Lai no, J. E., LeBlanc, J., \& Savoy, G. (2012). Production of natural folates by lactic acid bacteria starter cultures isolated from artisanal Argentinean yogurts. Can. J. Microbiol., 58, 581-588.

LeBlanc, J. G., Laino, J. E., Valle, M. J., Vannini, V., Sinderen, D. Van, Taranto, M. P., ... Sesma, F. (2011). B-Group vitamin production by lactic acid bacteria-current knowledge and potential applications. Journal of Applied Microbiology, 111, 1297-1309. https://doi.org/10.1111/j.1365-2672.2011.05157.x

LeBlanc, J. G., Taranto, M. P., Molina, V., \& Sesma, F. (2010). Vitamins, B-group, production by probiotic lactic acid bacteria. In F. Mozzi, R. Raya, G. Vignolo, \& A. I. B. of lactic acid bacteria: Novel (Eds.), Wiley-Blackwell, Ames (pp. 211-232).

Mani, L. E., Palou, E., \& López, M. A. (2014). Probiotic viability and storage stability of yogurts and fermented milks prepared with several mixtures of lactic acid bacteria. Journal of Dairy Science, 97(5), 2578-90. https://doi.org/10.3168/jds.2013-7551

Nakitto, A. M., Muyonga, J. H., \& Nakimbugwe, D. (2015). Effects of combined traditional processing methods on the nutritional quality of beans. Food Science \& Nutrition, 3(3), 233-41. https://doi.org/10.1002/fsn3.209

Paredes, L., \& Harry, G. I. (1989). Changes in Selected Chemical and Antinutritional Components during Tempeh Preparation Using Fresh and Hardened Common Beans. Journal of Food Science, 54(4), 968-970. https://doi.org/10.1111/j.1365-2621.1989.tb07923.x

Pompei, A., Cordisco, L., Amaretti, A., Zanoni, S., Matteuzzi, D., \& Rossi, M. (2007). Folate Production by Bifidobacteria as a Potential Probiotic Property. Appl. Environ. Microbiol., 73, 179-185.

Qaidi, S. El, Yang, J., Zhang, J., Metzger, D. W., \& Bai, G. (2013). The Vitamin B6 Biosynthesis Pathway in Streptococcus pneumoniae Is Controlled by Pyridoxal 5'-Phosphate and the Transcription Factor PdxR and Has an Impact on Ear Infection. Journal of Bacteriology, 195(10), 2187-2196. https://doi.org/10.1128/JB.00041-13

Snell, E. E. (1993). From bacterial nutrition to enzyme structure: a personal odyssey. Annual Review of Biochemistry, 62, 1-27.

Stanton, C., Gardiner, G., Meehan, H., Collins, K., Fitzgerald, G., Lynch, B. P., \& Ross, R. P. (2001). Market 
potential for probiotics. American Journal of Clinical Nutrition, 73(suppl.), 476S-483S.

Starzynska, A., Bozena, S., \& Mickowska, B. (2014). Effect of controlled lactic acid fermentation on selected bioactive and nutritional parameters of tempeh obtained from unhulled common bean (Phaseolus vulgaris) seeds. J Sci Food Agric, 94, 359-366. https://doi.org/10.1002/jsfa.6385

Thakur, K., Tomar, S. K., \& De, S. (2015). Minireview Lactic acid bacteria as a cell factory for riboflavin production. Applied Microbiology, Microbial Biotechnology, 9, 441-451. https://doi.org/10.1111/1751-7915.12335

UNICEF. (2011). United Nations Children Development Fund. The Global Prevalence of Anemia 2011. Geneva.

Vajaranant, K., \& Fields, M. L. (1989). The Production of Vitamin B6 by Microorganisms in Corn Meal. Journal of Food Protection: November, 52(11), 827-828.

Valle, J., Lainoa, J., Savoy, D., \& LeBlanc, J. (2014). Riboflavin producing lactic acid bacteria as a biotechnological strategy to obtain bio-enriched soymilk. Food Res Int, 62, 1015-1019.

\section{Copyrights}

Copyright for this article is retained by the author(s), with first publication rights granted to the journal.

This is an open-access article distributed under the terms and conditions of the Creative Commons Attribution license (http://creativecommons.org/licenses/by/4.0/). 